\title{
THE INFLUENCE OF SOCIAL MEDIA FRAMING ON AUDIENCE PERCEPTION OF ENDSARS AGENDA PROTEST
}

\author{
Chiemezie Chukwuka Ugochukwu \\ Department of Mass Communication \\ Nnamdi Azikiwe University, Awka \\ ugochukwuchiemezie@gmail.com
}

\section{Obiajulu Joel Nwolu}

Department of Mass Communcation

Nnamdi Azikiwe University, Awka

oj.nwolu@unizik.edu.ng

\begin{abstract}
In 2017, the \#ENDSARS hashtag began trending across social media platforms, calling for a scrap of a police unit Special Anti-Robbery Squad (SARS). Nigerians complained about the activities of SARS that include extortion, extra-judicial killing, and harassment, among others. The Nigerian government and Police authorities promised to overhaul the SARS activities despite calls to scrap the police unit. On October $3^{\text {rd }} 2020$, a video went viral across social media platforms how police officers suspected SARS officers shot a young man and took his Lexus car away. Social media influencers organized the protest and like wildfire, it spread across the country. Based on this, the research is structured to ascertain respondents' level of exposure to social media framing on EndSARS protest, to determine if social media framing on EndSARS protest motivated the youths, to find out if social media framing contributed to protests across the country. No doubt, the internet and social media have changed the narrative of organizing protests across the globe and Nigeria in particular. Anchored on three theories namely, framing theory, social category theory, and technology determinism theory. Survey research method was adopted for the study and copies of the questionnaire were distributed online with help of Google forms. Findings revealed that respondents were exposed to social media framing on EndSARS agenda and social media framing contributed to country's protest across the country. The study recommends, among others, that government should always investigate reports about its agencies and take proper action to forestall any protest in the future.
\end{abstract}

Key Words: Framing, Social media, SARS, Influence, Protest.

\section{INTRODUCTION}

The prediction by Marshal McLuhan about the global village has come to reality. Information and Communication Technology (ICT) have changed the entire landscape of gathering and sharing information among people irrespective of location and time in Nigeria. The Telecommunication industry has helped Nigerians to communicate with family members and friends through qualitative and innovative services they offer. Agreeing to this, Nwokedi (2020) said the advent of GSM in Nigeria has helped to fuel internet connectivity, thereby attempting to bridge the digital divide. Presently, various sectors of the Nigerian economy are hinged on ICT to increase performance and productivity. Telecommunication industry energized the growth of social media where millions of Nigerians share, upload and influence certain decisions in the country. Many scholars have acknowledged that social media have direct impact on good governance (Hasiya \& Abdullahi,2020) In 2001, the federal government of Nigeria under the presidency of Olusegun Obasanjo licensed the operations of telecommunication companies in Nigeria. It broke the barriers in communication as people can communicate to family members and friends anytime, any day. A breakthrough in telephone infrastructure emerged in January2001 when the sector was totally liberalized with the licensing of Mobile Telephone Networks (MTN) and Econet now Airtel as they injected over a million lines into Nigeria within a year (Isabona, 2013). This changed the landscape of 
DOI: doi.org/10.47851/naujocommed.v2i1.119

communication because many had access to reach and communicate with one another as government owned Telecommunication Company in Nigeria (Nigeria Telecommunication Limited NITEL) was not efficient. On August 29th 2003, Globacom Nigeria began its operation as first indigenous telecommunication company. After a year of operation in 2004, Globacom was the first telecom company to launch General Radio Packet Services (GPRS) which enabled the $2.5 \mathrm{G}$ technology with high speed data transmission and multimedia messaging services among other services (Osasere, 2013). This GPRS services by Globacom offered value for money as the innovation was a welcomed development. Globacom in 2003 introduced the concept of billing per second which The Massive customer base of the telecommunication industry has helped this sector to multiply9Mobile formally (Etisalat) moved into Nigeria telecom industry in 2008 following the milestone recorded by MTN, Glo and Airtel. 9mobile with 20 million subscribers are working on giving Nigerians quality and efficient services (Ohuocha, 2017). Major telecom giants in Nigeria are Mobile Telephone Networks (MTN), Globacom (Glo), Airtel, and 9Mobile. The merits of these telecommunication industries in Nigeria have created an economic impact, which the government derives through taxation and more people in the area of operation.) The government treasury has been significantly increased by the payment of over two hundred billion nairas of taxes and levies (Nkoredi, et al., 2017).

At the inception of MTN and Econet (now Airtel) the regulatory body that oversees the operations of telecommunications companies in the country, Nigeria Communication Commission (NCC) supervised and ensured that customers get value for money. Specific targets has been set for the operators by the NCC and some of these targets were a minimum of one hundred thousand subscribers each in the beginning year of operations, 1.5 million subscribers in the next five years, and a minimum of five percent geographical coverage within each of the country's geopolitical state (Nkordeh,Bob-Manuel \& Olowoni, 2017).

Social media is internet and computer based technology that aids in sharing of information, ideas and thoughts across a particular network. Globally, social media is a tool for expression of thoughts and ideas. In the words of Nwabueze (2014, p.170) social media are interactive, web-based media which engage key players in a communication channel in defining and determining the message content. The definition above, one can infer that social media users create messages and share to numerous users which influence them. Social media platforms include Facebook, Whatsapp, Twitter, Instagram, and Telegram among others. Active users are young people who own and use internet based phones, tablets and computers.

Special Anti Robbery Squad (SARS) is a unit of the Nigeria Police Force established to help curb violent crimes in the Nigerian society. No society is free from crime; hence the role of police is critical in ensuring law and order. Agreeing to the fact that no society is crime free, (Ijalana, 2018) said that "dynamic nature of human existence would not allow a cric3 me free society; criminal investigation and prosecution had become consequential duties for which police personnel are conferred with". At the creation of SARS in 1992, the objective was to help reduce armed robbery that was rampant at that time. Simon Danladi Midenda a superintendent of police at the inception was tasked with the formation of SARS and its mode of operation was secretive in order to ambush robbers (Chow,2020). With the mode of operation, SARS activities were mainly to uncover and arrest armed gangs. This police unit spread across the thirty-six states of the federation and its core mandate were arrest, investigation and prosecution of suspected armed robbers, murderers, kidnappers, hired assassins and other suspected violent criminals (news24.com). 
DOI: doi.org/10.47851/naujocommed.v2i1.119

Over the years, the rate of kidnapping and armed robbery has increased across the country and SARS whose job description entails arresting such criminals recorded a milestone in 2017 after successfully arresting a kidnap kingpin Chukwudi Onwuamadike known as "Evans". At that time, Evans was trailed by men SARS for five years, monitoring his communications and placed an eighty thousand dollars reward for information about him (news24.com).

The rising insecurity in the Northern Nigeria has been on the front burner of the federal government. SARS has helped most Northern States to curb the growing insecurity in that part of the country. This police unit (SARS) has been useful in the fight against insecurity in Northern region (Agbakwuru, 2020). Fighting terrorism should not be exclusively handled by Nigerian Army in order not overwhelm the army. In Nigeria, Bokoharam has badly destroyed the economic and social activities of Borno State. Despite the various attacks and killings, SARS has helped in the fight against terrorism in the state. According to Governor of Borno state, Prof Zulum SARS has played a role in counter insurgency operations by using their energy and aggression against Boko haram and supplemented the efforts of Nigerian military (Bashir \&Omirin, 2020).

In 2017, \#EndSARS symbol trended on various social media platforms and the main objective towards forming the symbol was to call the attention of Nigerian Government to a unit of Nigeria Police Force notorious for extra-judicial killing, torture and extortion of Nigerians. EndSARS began as a largely online movement, trending internationally on social media and gaining the support of figures including the footballer Marcus Rashford and the actor John Boyega (Akinwotu, 2020).The \#EndSARS began trending with hundreds of people sharing stories of abuse and assault which made the then Inspector-General of Police to announce plans to reorganize the team prosecute cases of human rights abuses and spearhead a better training program for recruits (Chow, 2020). Despite pleas and promises made by government and top hierarchy of the Nigeria Police Force, Special Anti Robbery Squad (SARS) harassed and intimated Nigerians leaving their mandate which is to arrest armed robbers and other armed related cases. The Vice President Prof. Yemi Osinbajo in August 2018 ordered the overhaul of SARS but allegations of abuse by SARS continued throughout the year (Malumfashi, 2020). Amnesty International documents at least 82 cases of torture, ill treatment and extra judicial execution by SARS between January 2017 and May 2020 (amnesty.org). On $3^{\text {rd }}$ October, 2020 a video went viral on different social media platforms. A young man was shot and his car taken away by men suspected to be SARS officials and it sparked protest across the country with \#EndSARS as the symbol.

Framing in communication is about how news item, event or happenings in the society is presented to the public. Goffman in 1974 views framing as the way people interpret what is going around them through the use of frames. Framing is the way a communication source defines and constructs any piece of communicated information (masscommtheory.com). On $3^{\text {rd }}$ October, 2020, a video of a young man shot by police officers suspected to be SARS went viral on different social media platforms. Users of social media framed the story and it generated emotions across the country and it degenerated to protest and violence in Nigeria.

In the light of the above, this study seeks to ascertain the influence of social media framing on audience perception of EndSARS agenda. 
DOI: $\underline{\text { doi.org/10.47851/naujocommed.v2i1.119 }}$

Securing lives and properties are the major role of police. At the inception of Special AntiRobbery Squad (SARS) in 1992 its mandate was to help fight crime like armed robbery, kidnapping, car theft among others. It was credited to have helped in reduction of crimes at the early years of operation. However, this police unit was accused of breeding corruption and flagrant abuse of human rights.

Amnesty International in its report documented at least 82 cases of torture, ill treatment and extra judicial executions by SARS officers between January 2017 and May 2020(Gladstone \& Specia, 2020). In 2017, a \#EndSARS was formed across many social media platforms with twitter taken the lead aimed at bringing the attention of Federal Government on the happenings in SARS. The then acting President, Prof. Yemi Osinbajo called for total overhauling of this police unit after series of agitations across the country.

On October 3rd, 2020, a video went viral across social media platforms showing how men of SARS killed a young man in Ughelli Delta state and took his Lexus SUV. Demonstrations erupted in Lagos and other cities, driven by calls from the people many of them young and organizing \#EndSARS agenda on social media demanding the Federal Government to eliminate the police unit (Gladstone \& Specia, 2020).

The \#Endsars movement began in 2017, as Nigerians shared experiences of police brutality via social media and demonstrations in several cities calling for SARS dissolution (Soladoye \& Ojo, 2020). In light of this, the study therefore seeks to ascertain the influence of social media framing on audience perception of EndSARS agenda in Nigeria.

\section{Objectives of the study}

- To ascertain respondents level of exposure to social media framing on EndSARS agenda.

- $\quad$ To determine if social media framing on EndSARS agenda motivated the youths.

- To find out if social media framing on EndSARS contributed to protests across the country.

\section{Research Questions}

- $\quad$ Are respondents' exposed to social media framing on Endsars agenda?

- $\quad$ Do social media framing on Endsars agenda motivate the youths?

- $\quad$ Do social media framing on Endsars contributed to protests across the country?

\section{THEORETICAL FRAMEWORK}

In research, theory serves as a beacon that holds or supports a research study. Several definitions have been given to theory by scholars and communication experts. To Mc Quail (2009), a theory is a system of law-like propositions and a systematic set of ideas that can help make sense of a phenomenon, guide action or predict a consequence.

In line with this work, "the influence of social media framing on audience perception of EndSARS agenda," this work is anchored on three theories, namely: Framing theory, Social Category theory, and Technology Determinism theory. 
DOI: $\underline{\text { doi.org/10.47851/naujocommed.v2i1.119 }}$

The foundation of framing theory lies on the impact in influencing the perception of a message by the audience. Framing theory simply explains how the media presents a story or news item to the audience (frame) and reinforces or influences how the audience interprets such story. Framing theory is believed to be similar to agenda setting theory. The theory of framing is closely tied to agenda setting theory because both focus on how media draw the public's eyes to specific topics thus setting agenda (Nwabueze, Igwenagu \& Obiakor, 2017). Prior to the Endsars agenda, in 2017 the online community of social media users launched \#ENDSARS to draw the attention of government to the growing corruption in Special AntiRobbery Squad (SARS). Many young Nigerians accused this police unit of violation of Human Rights that include illegal "stop and search", illegal arrests and detentions, extrajudicial killings, sexual harassment and brutalizing of young Nigerians. There were recorded videos, pictures of victims of SARS brutality which social media users shared across different platforms. The videos and pictures about SARS brutality formed the frame of stories that ignited the Endsars agenda across the country. The EndSARS agenda in Nigeria took prominence across various social media platforms because the users of these social media tools assumed the role of citizen journalist reporting the events that featured in the nationwide protest.

Entman 1991 cited in 0so 2017 identified five popular ways for framing news story namely:

- $\quad$ Conflict: Conflict between parties being prioritized.

- $\quad$ Human Interest/ Personalization: Presenting story with human face.

- $\quad$ Consequence: Pursuing a policy within a party or globally.

- $\quad$ Morality: Media coverage based on morality.

- Responsibility: Attributing responsibility, either for a course or a solution. in Nigeria.

In line with the study, this theory highlights the role of framing on EndSARS protest

\section{Social Category Theory}

This theory believes that individuals or groups that are in the same category of age, occupation, sex among others perceive or react to media messages in a similar way. Its basic tenet is that mass media audience members exist in sub-groups or social category and that each sub-group or social category influences decisions on which media members of each group or category are exposed to and how to use or perceive the media content (Nwabueze,2014 p.48). Furthermore, social category theory is premised on individuals within broad subgroups (like social, age, sex etc) that react similarly to the mass media message.

When officers of SARS shot a young man in Ughelli ,Delta State and took away his Lexus SUV because of the belief that that the young man is an internet fraudster (yahoo yahoo), young Nigerians whose source of livelihood are questionable (Internet fraudster) were believed to have organized a protest that spread like wild fire in Nigeria. According to Ekoh \& Geroge, (2021), young people in Nigeria are now protesting both on social media and in the streets of Nigeria against police brutality and for further reform of Nigeria as a whole. Social category theory explains that the EndSARS agenda were dominated by young Nigerians due to the belief that SARS molest and infringe on the rights of young Nigerians. SARS officers can be seen on roads and streets of Nigeria looking for young persons who they profile as criminals or yahoo boys (internet fraudsters) simply by observing certain features such as wearing of dreadlocks, tattoos, having an Iphone, having a laptop computer, driving a car (especially a Mercedes Benz) or generally looking wealthy (Ekoh Geroge,2021). The protest held across the cities of Nigeria because the youths believe th 
DOI: doi.org/10.47851/naujocommed.v2i1.119

are victims' of SARS brutality which the theory states that individuals in same age category react to messages in similar way.

\section{Technology Determinism Theory}

This theory was postulated by Canadian scholar Marshal McLuhan. The foundation of this theory is that technology is at the centre of communication and it shapes the direction of events in the society. Mc Luhan posited that a change in modes of communication shapes human existence and inventions in technology invariably cause cultural changes (Griffin, 2000 cited in Nwabueze, 2014p.56). The theory explains the role of technology in shaping the cultural orientation, values and events in the larger society. Social media is driven by the internet across the countries of the world, and it is valuable tool that will revolutionalize the globe (Ugochukwu, 2020). Internet has enabled technology determinism theory to achieve the postulation of McLuahn. The EndSARS agenda in Nigeria was organized across social media platforms and millions of Nigerian youths trooped out to the street to protest. The EndSARS protest was achieved with technology (social media) affirming the position of McLuhan that technology influence the events in the society.

\section{LITERATURE REVIEW \\ Nigeria Police and Information and Communication Technology (ICT)}

Across the globe, police is critical in any society to ensure protection of lives and properties and serve as a beacon that holds and protect the society. Simply put, police is an institution empowered by a state with the purpose to enforce, maintain law and safety of the people. In any democratic country, there are provisions in the constitution that backs the responsibilities of the police in order to achieve its mandate of protecting lives and properties. The 1999 constitution of Federal Republic of Nigeria clearly stipulates the role of Nigeria Police Force to Nigerians. Section 214(1) of the constitution as amended states that the police shall be engaged to; (1) Prevention of crimes (2) Protection of lives and properties (3) Preservation of law and order (4) Arrest of crime offenders (5) Crime detections and detention of criminals (6) Performance of military duties within and outside Nigeria as directed of them by government (7) Due enforcement of all laws and regulations with which they are directly charged (8) Person Identification (9) Search through belongings (10) Section 23 of the police Act adds the prosecution of criminal cases. (Cap 19 of Police Act, Federal Republic of Nigeria 1999 in Iheriohanma, Opara\& Raimi (2020).

The impact of Information and communication Technology (ICT) also known as internet has changed the information and communication gathering techniques. With the help of internet, access to information especially as regards crime prevention, intelligence gathering and sharing helps the police to be more professional and efficient in the discharge of their duties. The advent of handheld devices, smart phones and tablets, backed by access to large amount of public and police- specific data means that there is potential for officers to be better informed and make proper use of their time than before (Anderson, 2013).

Presently in Nigeria, various sectors of the economy are going digital because of ICT growth and development. The Nigeria police should totally embrace this technology to enhance its performance. Countries like America and United Kingdom have digital policing to help reduce and fight crime. A digital policing model in the context of Nigeria is the integration of digital component into the policing apparatus of the Nigeria Police Force Idris et al (2019). 
DOI: $\underline{\text { doi.org/10.47851/naujocommed.v2i1.119 }}$

This simply means changing paper based investigation to a digital investigation to broaden knowledge and develop the police investigating processes. The major reason crime keep increasing is the use of analog method in investigation and tracking of criminals in a world of digital era. Adopting the digital Police can help proffer solutions to crimes associated with technology driven crimes and cyber criminals. Digital policing involves the use of digital technology to transform the way policing is delivered by integrating the society, virtually with the Police stations, thus bringing the police closer to communities and crime spot Idris et al (2019).

The fact that Nigeria Police needs tom totally adopt digital policing is not in doubt. Due to corruption and poorly trained officers, adopting e-policing across the command, zonal offices and numerous police stations will be a difficult task to be achieved. However, a committed Federal Government can overhaul the Police Force if it has the political will to effect a change. In achieving a digital Nigeria Police Force in Nigeria, Idris et al (2019) listed several factors and they include; (1) Proactive policing (2) Digital public engagement and digital contact management (3) Mobile workforce optimization (4) Digital Investigation (5) Online crime reporting (6) Live streaming of video footage into control rooms (7) Police adoption of the cloud (8) Digital skills in policing (9) Smarter procurement and accessing innovation.

\section{Public Relations and Police Image}

Managing and projecting an institutional image for public acceptance requires sustained and strategic planning to achieve. Public relations are often mistaken for advertising a product or brand but public relations cuts across that. Innovations in media that led to the growth and improvement in social media have changed the channels through which public relations messages are disseminated.

Public relation is a set of communication programs employed to create and maintain favorable relationship between an organization and its publics. Maintaining and managing the image of Nigeria Police Force entails a professional to handle to ensure a favorable public image. According to British Institute of Public Relations, public relations can be defined as the deliberate, planned and sustained effort to establish and maintain mutual understanding between an organization and its publics (Black, 1991 in Agbanu 2008, p.408).

Due to perception that Nigerians have about the Nigeria Police Force, the Force Public Relations Unit (FPRU) was established to ensure a smooth relationship with members of the public. At the Police Force headquarters in Abuja the police public relation serves as the image maker. This unit is headed by senior police officer in the rank of Assistant Commissioner of Police at Force headquarters while at the state command an Assistant Superintendent of Police heads the unit. The public relations unit of the Nigeria Police force performs tasks that mirror the image of the force in good light. Affirming this, Mathias,(2016) said that the PR unit publishes list of wanted persons, missing persons, stolen vehicles, dark spots, security tips, press briefings, articles through the print and electronic medium. This showcase that Public relation unit of Nigeria Police Force keeps the member of the public on its activities and happenings as it concerns Nigerians. Although many argue that the image of Nigeria Force over the years has not been a good one. In proffering practical public relation activity that will enhance the image of the police, Orzekauska \& Smaiziem (2007) in Oluwasola (2016) listed several public relation strategies they include: (1) Back grounding police image (2) Analyzing internal \& external environment (3) Determine desirable image for the police (4) Measuring present image of the police (5) Identifying 
DOI: doi.org/10.47851/naujocommed.v2i1.119

police image through research (6) Preparing a plan for reducing gaps (7) Implementing program and evaluating its impact. The listed public relation strategies can help if carefully studied and implemented across various formations of Nigeria Police force by trained experienced public relations expert. In achieving a better image management for the Nigeria Police Force, public relation practitioner should adopt theories of public relation to achieve a better image. Basically, for the purpose of the study three theories of public relation will be analysed in relation to image of Nigeria Police. They include two way symmetrical theory, public relation transfer model and cultivation theory. The two way symmetrical theory is principally built on communicating with the key audience by the public relation practitioner and serve as a link between an organization and key publics. Propounded by Grunig and Hunt in 1984, this theory points that in achieving effective public relation for an organization, the communication must be two way information dissemination process to achieve a feedback

Oluwasola (2016).Nigeria police as an institution that primarily protects lives and properties should adopt this theory in modeling its image in order to be seen as socially responsible by members of the public. Although the Force Public Relation Unit of the Nigeria police has done a lot in managing the image of Police, more work needs to done to achieve a better image.

Public relation transfer model is a theory of public relation built on using public relation tools and strategies to change the negative narratives about an organization. Propounded by Frank Jefkins in 1988 this theory is built on using public relation enlighten the various publics of an organization about the positive attributes. Public relation transfer model explains how practitioners can use and apply public relation tools and strategies towards changing hostility among an organization target publics to sympathy to be in a better position to convert prejudice into acceptance, develop interest where apathy is and communicate effectively to achieve knowledge where there is ignorance Oluwasola (2016). The Nigeria Police needs to vigorously adopt and critically examine its public relation activities to this theory to achieve better and friendly policing.

\section{METHODOLOGY}

This work adopted survey research method. The choice of the method lies on the strength of survey research to allow the researcher select from a sample of the entire population. In using survey design, questionnaire was deployed to generate data for the study. Questions were drawn from the research objective for the questionnaire to get responses from the respondents. Population of study was drawn from a group in Facebook named AY Comedian facebook page with active followers of 6,986,061. The sample size of 399 was drawn from the population using the Taro Yamani formula. Copies of the questionnaire were shared on the page of AY Comedian group and the questionnaire was distributed via online using the Google form. A total of 380 copies of questionnaire were filled and submitted online. Data generated was analyzed using simple percentage tables for easy understanding.

\section{DATA PRESENTATION}

Table 1: Gender of respondent

\begin{tabular}{|l|l|l|}
\hline Gender & No of Respondents & Percentage \\
\hline Male & 260 & $68 \%$ \\
\hline \multirow{2}{*}{ ORexCommpan2021 } \\
\hline
\end{tabular}


NNAMDI AZIKIWE UNIVERSITY JOU

Journal OF COMMUNICATION HND MEDL STUDIES

Volume 2 Number 1 Jan-Mar Issue

DOI: $\underline{\text { doi.org/10.47851/naujocommed.v2i1.119 }}$

\begin{tabular}{|l|l|l|}
\hline Female & 120 & $32 \%$ \\
\hline Total & 380 & 100 \\
\hline
\end{tabular}

Field work, 2021

Analysis in table 1 shows that 68 percent of the respondents are male while 32 percent of respondents are female. It shows that majority of the respondents are male.

Table 2: Age of Respondents

\begin{tabular}{|l|l|l|}
\hline Classification & No of Respondents & Percentage \\
\hline $18-25$ & 120 & $32 \%$ \\
\hline $26-33$ & 100 & $26 \%$ \\
\hline $34-41$ & 95 & $25 \%$ \\
\hline 50 years above & 65 & $17 \%$ \\
\hline Total & & 100 \\
\hline
\end{tabular}

Field work, 2021

Table 2 indicates that those in the age range of 18-25 years participated more in the protest. Those in the age category of 26-33 had 26 percent, while 34-41 age categories had 25 percent. The least age category that participated in the protest was 50 years and above with 17 percent.

Table 3: Marital status of Respondents

\begin{tabular}{|l|l|l|}
\hline Status & No of Respondents & Percentage \\
\hline Married & 65 & $17 \%$ \\
\hline Single & 280 & $74 \%$ \\
\hline Divorced & 35 & $9 \%$ \\
\hline Total & 380 & 100 \\
\hline
\end{tabular}

Field work, 2021

The single respondents had 74 percent of the entire people that participated in the protest. It was followed by married people with 17 percent and divorced respondents were the least with 9 percent.

Table 4: Educational Qualifications of Respondents

\begin{tabular}{|l|l|l|}
\hline Qualifications & No of Respondents & Percentage \\
\hline
\end{tabular}


NNAMDI AZIKIWE UNIVERSITY JOU

Volume 2 Number 1 Jan-Mar Issue

Journal OF COMMUNICATION AND MEDL STUDIES

DOI: $\underline{\text { doi.org/10.47851/naujocommed.v2i1.119 }}$

\begin{tabular}{|l|l|l|}
\hline SSCE & 30 & $8 \%$ \\
\hline OND & 50 & $13 \%$ \\
\hline HND & 80 & $21 \%$ \\
\hline Bachelors & 160 & $42 \%$ \\
\hline Masters & 40 & $11 \%$ \\
\hline Doctorate & 20 & $5 \%$ \\
\hline Total & 380 & 100 \\
\hline
\end{tabular}

Field work, 2021

Respondents with SSCE had 8 percent, OND respondents with 13 percent and HND with 21 percent. Respondents with bachelors' degree have the highest with 42 percent, while masters had 11 percent and the least is doctorate with 5 percent.

Table 5: The level of exposure about EndSARS protest on social media

\begin{tabular}{|l|c|c|}
\hline Response & No of Respondents & Percentage \\
\hline Always & 300 & $79 \%$ \\
\hline Sometimes & 50 & $13 \%$ \\
\hline Rarely & 20 & $5 \%$ \\
\hline Can't say & 10 & $3 \%$ \\
\hline Total & 380 & 100 \\
\hline
\end{tabular}

Field work, 2021

From the analysis, 79 percent are always exposed to EndSARS agenda in the social media, while 13 percent are exposed sometimes. Respondents that rarely got exposed to social media on EndSARS agenda had 5 percent and 3 percent of respondents can't say if they were exposed to social media about EndSARS protest.

Table 6: If social media motivated the youths to join the protest

\begin{tabular}{|c|c|c|}
\hline Response & No of Respondents & Percentage \\
\hline Strongly Agree & 230 & $60 \%$ \\
\hline Agree & 60 & $16 \%$ \\
\hline Undecided & 30 & $8 \%$ \\
\hline Disagree & 40 & $11 \%$ \\
\hline $\begin{array}{c}\text { Strongly } \\
\text { Disagree }\end{array}$ & 20 & $5 \%$ \\
\hline Total & 380 & 100 \\
\hline
\end{tabular}

Field work,2021

From the analysis, 60 percent of the respondents strongly agree that social media motivated them to join the Endsars agenda, while $16 \%$ agreed that social media made them join the Endsars agenda. Only $5 \%$ of respondents said that the social media did not motivate them to join the Endsars agenda. 
Table 7: If social media framing on EndSARS agenda contributed to its spread across Nigeria

\begin{tabular}{|l|l|l|}
\hline Response & No of Respondents & Percentage \\
\hline Yes & 340 & $89 \%$ \\
\hline No & 30 & $8 \%$ \\
\hline Can't say & 10 & $3 \%$ \\
\hline Total & 380 & 100 \\
\hline
\end{tabular}

Field work, 2021

The number of respondents that said that social media framing on EndSARS contributed to the spread of the protest across the country is 89 percent of the respondents. Eight percent of the respondents said no while 3 percent of the respondents can't say.

\section{DISCUSSION OF FINDINGS}

On the research question which sought to determine if social media framing on EndSARS agenda motivated the youths, findings revealed that the youths were motivated to join the protest with 63 percent affirming that social media motivated them. This finding agrees with Kazeem(2020) where he said that 'twitter and whatsapp messages on EndSARS agenda were used to mobilize the young people to organize the protest across the country. Social media platforms played vital roles during the nationwide protest due to its features that allow young people to connect and meet in various locations. Also the various activities of EndSARS promoters were shared across social media platforms and it helped to mobilize thousands of youths across the country.

The research question that ascertained respondents' level of exposure to social media framing on EndSARS agenda, 79 percent of the respondents were exposed to social media framing on EndSARS. The report of Ruppel \&Arowobusoye (2020) said that "the outcry against SARS became louder as the usage of social media increased in Nigeria, handled by young people who documented and shared the alleged atrocities of SARS on social media platforms. From this report, it shows that various extra judicial killings and torture by SARS officials that was recorded and shared on the internet and various social media platforms exposing the youths on the activities of this police unit and formed an opinion about them in their minds.

Although the October 3, 2020 incident (Ugheli video) incident that sparked the protest across the Nation, there have been outcry to disband SARS. Nigerians also shared stories about their inhumane treatment and provided video evidence of how members of SARS engaged in crimes such as kidnapping, rape, theft, unlawful detention, torture and murder (Latif, 2020). These stories about SARS shared online exposed many Nigerians to the activities of this police unit, hence the justification to join the protest. Brown \& Olubanji,(2020) agreed that the Ughelli video generated an unprecedented up swell of emotions on social media, especially twitter which played an influential role at the protest. 
The third research question which sought to find if social media framing on EndSARS contributed to protests across the country, 89 percent of respondents believed that social media framing contributed to the protest. Stories, pictures and live videos uploaded on different social media platforms sustained and grew the population of young Nigerians that participated in the protest. Dark, (2020) agreed that social media simplified the EndSARS movement allowing users with varying numbers of followers to pitch, improve or reject ideas, solicit donations or start food banks to feed the protesters. This motivated protesters from other states to join the protest which lasted for days. Also, EndSARS organizers used social media to connect with volunteers accept donations from other parts of the world and publish accounts of disbursed funds through frequent updates (Dark, 2020). The EndSARS protest in Nigeria triggered and opened a lot about officers of Nigeria Police force which many Nigerians believe is rooted in years of corruption.

\section{CONCLUSION}

This study has shown that social media is not only for entertainment; rather it can be used to mobilize and effect social change in the society. The technology that drives social media keeps getting better and users increase daily especially the youths. The Ughelli incident that triggered the EndSARS agenda in Nigeria was organized on social media and the \#EndSARS was the symbol across various social media platforms. Anchored on three communication theories namely; framing theory, social category theory and technology determinism theory. Findings from the study revealed that social media framing on EndSARS protest motivated the youths across the country to join the protest that lasted for two weeks. Also, the study found that social media framing contributed to the protest across the country and the EndSARS agenda projected the image of Nigeria police force in the negative. Finally, social media has come to stay and youths can rightly deploy it so that their voices can be heard.

\section{RECOMMENDATIONS}

- Government and its agencies should investigate and sanction reports about them on social media platform.

- Government should encourage its citizens to always speak up whenever there rights are infringed on through appropriate channels and various social media platforms.

- $\quad$ Social media campaigns should be organized across social media platforms to help build a better image for the Nigeria Police Force.

\section{REFERENCES}

Agbakwuru, J. (2020). Northern Governors want SARS- Lalong. Accessed from http:vanguardngr.com on $6^{\text {th }}$ January,2021

Agbanu, V. \& Nwabueze, C. (2008). Readings in Mass Communication. Global Perspectives on Communication Issues. Owerri: Top Shelve Publishers.

Akinwotu, E. (2020). Nigeria to disband SARS police unit accused of killing and brutality. Accessed from http://theguardian.com on $5^{\text {th }}$ January,2021.

Anderson, T. (2013). Technology on the beat: How IT can enhance policing. Accessed fron 
DOI: $\underline{\text { doi.org/10.47851/naujocommed.v2i1.119 }}$

http//theguardi an.com on $5^{\text {th }}$ January,2021.

Bashir, M.\&Omirin, O. (2020). Zulum supports SARS, wants personnel drafted into counter insurgency Fight. Accessed from http: dailytrust.com on $20^{\text {th }}$ December,2020.

Brown, L \&Olubanji, W. (2020). Nigeria youth rises up. Accessed from http:ips-journal.eu on January $5^{\text {th }}, 2021$.

Chow, A. (2020). The Nigerian Government has pledged to ENDSARS and reform the police. This isn't the first time they have made the promise. Accessed from http:time.com on $6^{\text {th }}$ January,2021.

Dark, S. (2020). How Nigerians harness social media against police abuse. Accessed from Aljazeera.com on $23^{\text {rd }}$ December,2020.

Ekoh, P. \& Geroge, E.(2021). The Role of Digital Technology in the Endsars Protest in Nigeria During COVID 19 Pandemic. Accessed from Link.springer.com on $8^{\text {th }}$ April, 2021.

Gladstone, R ,Specia M. (2020). Nigeria's Police Brutality crisis: What's happening now. Accessed from http: nytimes.com on $23^{\text {rd }}$ December,2020

Hasiya, I \& Abdullahi, A. (2020). The Effect of Social Media on Good Governance in Nigeria. $4^{\text {th }}$ International conference of Democracy and good governance in Africa

Lapai. Kano State. Accessed from http//researchgate.net. on $12^{\text {th }}$ April, 2021.

Idris,I., Victor, L. et al (2019). Towards a digital policing in Developing Nations: The Nigeria context. International Journal of Innovation Technology Exploring Engineering. Accessed from Ijitee.org on $22^{\text {nd }}$ December, 2020.

Iherioharnma, E., Opara, O \& Raimi, L. (2020). The Nigeria Police Force and its constitutional responsibility in the present democratic dispensation. Accessed from $\mathrm{http} / /$ Journalissues.org on $23^{\text {rd }}$ December,2020.

Ijalana, E. (2018). The Police in Nigeria: Meaning, Foundation, Scope and Essence. Journal of Law, Policing and GlobalizationI. International Journal of Innovation Technology Exploring Engineering Accessed from http:iiste.org on $23^{\text {rd }}$ December,2020.

Isabona, J. (2013). Harnessing telecommunication revolution in Nigeria: A case study. Accessed from http: pubssciepub.com on $23^{\text {rd }}$ December,2020.

Kazeem, Y. (2020). How a youth-led digital movement is driving Nigerians largest protests in a decade. Accessed from google.com/amp on $23^{\text {rd }}$ December, 2020.

Latif, R. (2020). Is social media responsible for International Solidarity?Accesed from http:redbrick.me on $23^{\text {rd }}$ December, 2020.

Malumfashi, S. (2020). Nigeria's SARS: A brief history of the Special Anti-Robbery Squad 
Accessed from http:aljazeera.com on $23^{\text {rd }}$ December, 2020.

Mathias, J. (2016). Police Public Relation as a potent tool Management for combating crime,insecurity and social disorder in Nigeria. Journal of Business \& Invention. Accessed from http/ijbmi.org on $22^{\text {nd }}$ December, 2020.

Mc Quail, D. (2009). Mass Communication Theory (6 ${ }^{\text {th }}$ edition). London: Sage publication. Nsikan, N Ibinabo, B Olowonon, F. (2017). The Nigerian Telecommunication Industry: Analysis of the first fifteen years of the growth and challenges in the GSM market (2001-2016). World Congress on Engineering and Computer Science vol 1. Accessed from .eprints.convenantuniversity.edu.ng on $22^{\text {nd }}$ December,2020.

Nwabueze, C. ,Igwenagu, E. \&Obiakor C. (2017). Press Coverage of World Tobacco Day in Nigeria (2014-2016) and smokers Journalists Attitude towards Coverage of the event. Journal ofMass Communication Journalism. Accessed from http:researchgate.net/publication on $22^{\text {nd }}$ December,2020.

Nwokedi, V. (2020). Bridging the Digital Divide in Information Technologies: Nigeria Experience.Accesed From http//academicresearchjournals.org on $11^{\text {th }}$ April,2020.

Ohuocha, C. (2017). Telecoms regulator approves Etisalat Nigeria name change. Accessed from http:reuters.com on January $6^{\text {th }}, 2021$.

Oluwasola, O. (2016). An assessment of Public Relation as a tool for repositioning the image of Nigeria Police Force. A study of Lagos State Command. Accessed from Http: iiardpub.org on $3^{\text {rd }}$ January, 2021.

Osasere, M. (2013). Decade of Glo. Accessed from http://thenationonlineng.net on $3^{\text {rd }}$ January,2021.

Oso, L (2017). Understanding the Framing Theory. Accessed from http: researchgate.net on $3^{\text {rd }}$ January,2021.

Soladaoye \& Ojo (2020). Impact of Social Media on Police Brutality Awareness in Nigeria. International Journal for Management \& Modern Education. Accesed from http//ijmme.com on $10^{\text {th }}$ April, 2021.

Ugochukwu, C. (2020). Evaluation if Social Media Influence in the Fight against Corruption in Nigeria. Journal of Communication and Media Studies. Vol. 1 No 1 (149-161). 